\title{
Trans-, cis-, and dihydro-resveratrol: a comparative study
}

\author{
Natalia YU Anisimova', Mikhail V Kiselevsky ${ }^{1}$, Andrey V Sosnov ${ }^{2}$, Sergey V Sadovnikov ${ }^{3}$, Ivan N Stankov ${ }^{3}$ and \\ Andrei A Gakh ${ }^{*}$
}

\begin{abstract}
Background: Recent studies showed that moderate consumption of red or white wines increased the chances of breast cancer, while similar consumption of red wines, rich in trans-resveratrol (trans-R), decreased the rate of prostate cancer. This prompted us to explore the role of various forms of $\mathbf{R}$ in cancer proliferation.

Results: Trans-R was found to be the most potent antiproliferative agent. Cis- $\mathbf{R}$ demonstrated somewhat less

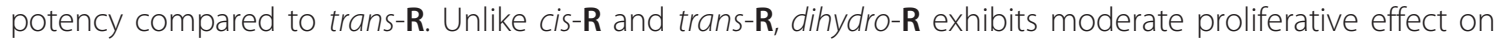
androgen-independent prostate cancer cell lines PC-3 and DU-145 at picomolar concentrations. At higher

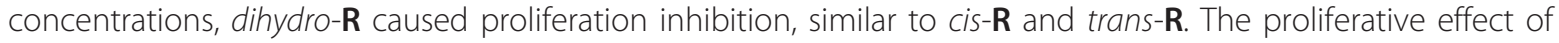
dihydro- $\mathbf{R}$ at low concentrations can be reversed by trans- $\mathbf{R}$ which acts as a partial antagonist in the presence of dihydro-R. Mixtures of dihydro- $\mathbf{R}$ and trans-R demonstrated complex non-monotonic cross-modulation activity patterns.

Conclusions: Dihydro-R exhibits proliferative effects in androgen-independent prostate cancer cells at picomolar and nanomolar concentrations. While the exact mechanism of these effects requires further evaluation, our preliminary results point to hormone receptor modulation activity. We also observed strong cross modulation between trans-R and dihydro- $\mathbf{R}$ at sub-picomolar concentrations. The role of dihydro- $\mathbf{R}$ in cancer proliferation related to moderate consumption of red wine remains an open question because dihydro- $\mathbf{R}$ has a very complex activity pattern in the presence of trans-R.
\end{abstract}

\section{Background}

The term "French Paradox" was introduced by S. Renaud in the early 1990s to describe the low incidence of heart disease and obesity among the French in contrast to their relatively high-fat diet [1]. It is widely believed that consumption of red wine, rich in transresveratrol (trans-R) and other dietary polyphenols, is the primary cause of this paradox. Given the well-documented anticancer properties of trans- $\mathbf{R}$, it is natural to expect that the moderate consumption of red wine might bring additional benefits of lower cancer rates, especially the most frequent forms of cancer such as breast and prostate cancer. However, recent studies have unequivocally demonstrated that even moderate consumption of red or white wines markedly increased

\footnotetext{
* Correspondence: gakhaa@yahoo.com

${ }^{4}$ National Institutes of Health, NIDDK, 8 Center Drive, Bethesda, MD 20892 , USA

Full list of author information is available at the end of the article
}

the chances of breast cancer [2-4], while moderate consumption of red wine substantially decreased the rate of prostate cancer [5]. It was also reported that moderate consumption of white wine or beer does not affect prostate cancer rate [5]. Although the alcohol content should be considered as a prime factor responsible for this intriguing disparity between the cancer types [2-5], this unusual situation prompted us to further explore the role of resveratrol (R) in prostate cancer proliferation.

Like any food product, red wine contains a complex mixture of structurally related organic compounds. One of these compounds is $\mathbf{R}$. The predominant trans- $\mathbf{R}$ comes along with a lesser-known companion, cis-resveratrol (cis-R), and they are almost always present in red wine together (Figure 1). We recently discovered [6] that the GC-MS peak of cis-R was usually accompanied by a close peak of another polyphenol having molecular weight 2 Da higher than cis-R. Independent synthesis 
<smiles>Oc1ccc(/C=C/c2cc(O)cc(O)c2)cc1</smiles>

Trans-R

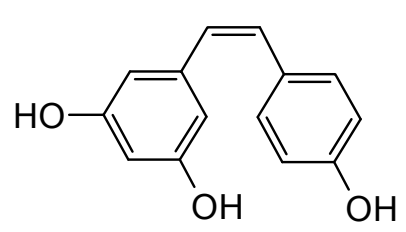

Cis- $\mathbf{R}$<smiles>Oc1ccc(CCc2cc(O)cc(O)c2)cc1</smiles>

Dihydro-R

Figure 1 Structures of trans-resveratrol (trans-R), cis-resveratrol (cis-R), and dihydro-resveratrol (dihydro-R) isomers.

confirmed that this peak is the peak of the third form of $\mathbf{R}$, dihydro-resveratrol (dihydro-R). Dihydro- $\mathbf{R}$ is a wellknown metabolite of trans-R [7], but it had not been identified in red wines before the study [6].

In our experiments dihydro- $\mathbf{R}$ demonstrated strong proliferative properties in hormone-dependent cell lines (such as MCF-7) at picomolar $\left(10^{-12} \mathrm{M}\right)$ concentrations [6]. The effect was not observed in cell lines without estrogen receptors, and the proliferative effect could be reversed by the action of estrogen antagonists, such as the known breast cancer drug Tamoxifen. This is consistent with the assumption that dihydro- $\mathbf{R}$ is a potent phytoestrogen, even though the conformationally flexible chemical structure of dihydro- $\mathbf{R}$ makes it a very unlikely analog of $17 \beta$-estradiol and other synthetic nonsteroidal estrogens such as diethylstilbestrol (DES) [6].

Given the preceding, it is reasonable to assume that the presence of dihydro- $\mathbf{R}$ in red wines could be partially responsible for the difference observed between breast cancer and prostate cancer in relation to moderate wine consumption. To explore this further, we initiated a comparative study of the biological effects of the three forms of $\mathbf{R}$ found in red wines on two androgen-independent human prostate cancer cell lines (PC-3 and DU-145) and one hormone-dependent breast cancer cell line (MCF-7) in vitro. This paper presents the results of our work.

\section{Results and Discussions}

To investigate the ability of trans-R, cis- $\mathbf{R}$, and dihydro$\mathbf{R}$ to control the growth of PC-3 prostate cancer cells, various concentrations of these compounds were added to tumor cell cultures and then incubated for $48 \mathrm{~h}$. Figures 2 and 3 show the tumor cell viability after exposure to these agents.

The cytotoxic effect of trans-R was observed at concentrations of $1 \times 10^{-7}$ to $1 \times 10^{-4} \mathrm{M}$. Similarly, the cytotoxic effect of cis- $\mathbf{R}$ was observed at concentrations $1 \times 10^{-6}$ to $1 \times 10^{-4} \mathrm{M}$. The results indicated that trans$\mathbf{R}$ is somewhat more effective as an anticancer agent than cis-R. Dihydro-R, in contrast to trans- $\mathbf{R}$ and cis- $\mathbf{R}$, had a biphasic effect. At high concentrations $\left(1 \times 10^{-5}\right.$ to $1 \times 10^{-3} \mathrm{M}$ ), dihydro- $\mathbf{R}$ showed the typical for this class of compounds decrease in the growth rate of tumor cells. However, treatment with $1 \times 10^{-10}$ to $1 \times 10^{-}$

${ }^{7} \mathrm{M}$ of dihydro- $\mathbf{R}$ significantly increased the growth of PC-3 prostate cancer cells (Figure 2).

Further comparative evaluation of the biological activity of trans-R and dihydro- $\mathbf{R}$ was performed using the DU-145 prostate cancer cell line. Again, trans- $\mathbf{R}$ displayed only cytotoxic properties whereas dihydro- $\mathbf{R}$ had a biphasic effect, similar to the one observed in PC-3 cells. At high concentrations $\left(1 \times 10^{-5}\right.$ to $1 \times 10^{-}$ $\left.{ }^{3} \mathrm{M}\right)$, dihydro- $\mathbf{R}$ decreased the rate of growth of DU145 tumor cells. Treatment with low concentrations (1 $\times 10^{-10}$ to $1 \times 10^{-8} \mathrm{M}$ ) of dihydro- $\mathbf{R}$ significantly increased the growth of DU-145 prostate cancer cells (Figure 3).

The observed cytotoxic effects of both trans- $\mathbf{R}$ and cis$\mathbf{R}$ in androgen-independent prostate cancer cell lines are in agreement with the previously reported data. Trans- $\mathbf{R}$ is a known inhibitor of human prostate cancer cell growth at concentrations of $1 \times 10^{-6}$ to $1 \times 10^{-4} \mathrm{M}$ (e.g., $\operatorname{GI}(50)=2.41 \times 10^{-5} \mathrm{M}$, DU-145 [8]) depending on the prostate cancer cell line and experimental conditions [9]. The biphasic action of the third form of $\mathbf{R}$, dihydro- $\mathbf{R}$, in

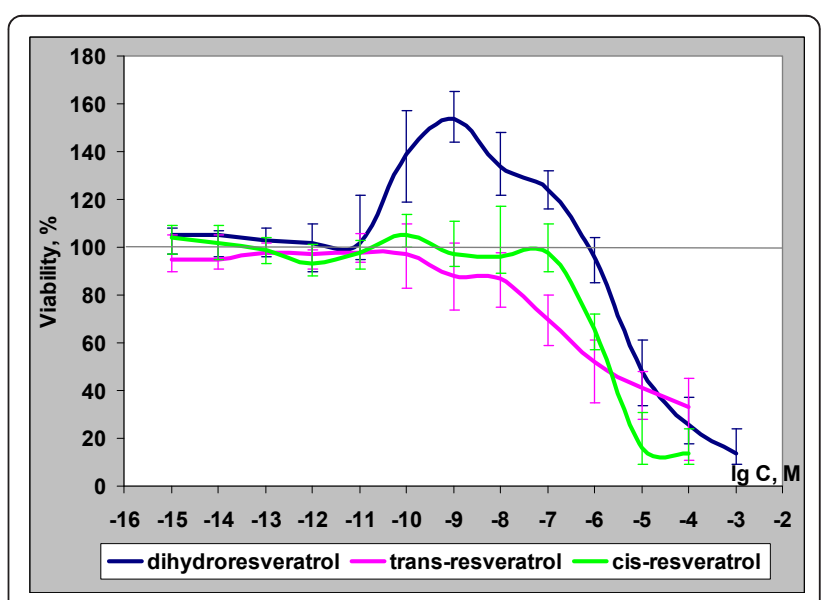

Figure 2 Biological activity of dihydro- $\mathrm{R}$, trans- $\mathrm{R}$ and cis- $\mathrm{R}$ in the PC-3 cell line. 


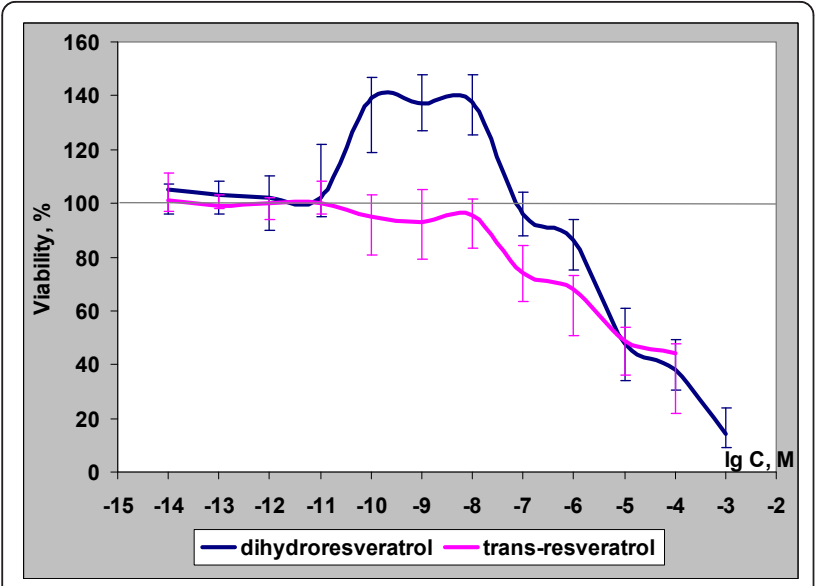

Figure 3 Biological activity of dihydro-R and trans-R in the DU145 cell line.

comparison with the better studied trans- $\mathbf{R}$ requires further evaluation, especially in relation to estrogen receptors [6] present in both the PC-3 and the DU-145 prostate cancer cell lines [10-14].

The biological effects of trans- $\mathbf{R}$ in androgen-independent prostate cancer cell lines can be attributed to a variety of specific molecular targets, including estrogen and androgen receptors [15]. Unfortunately, the exact mechanism of the hormone receptor-mediated activity of trans- $\mathbf{R}$ is poorly understood because of the apparent complexity of the underlying biological functions of these receptors in prostate cancer cells. For example, it is well documented that $17 \beta$-estradiol (E2) inhibits growth of androgen-independent PC-3 cells [10] but stimulates growth of androgen-dependent LNCaP cells, presumably via its own receptor [16]. The situation is even further complicated by the existence of two estrogen receptors (ERs), ER- $\alpha$ and ER- $\beta$, in prostate cancer cells [11]. As a result, growth of PC-3 cells, which have both ER subtypes, can be effectively inhibited by estrogens as well as antiestrogens [17]. In contrast, DU-145 cells express only ER- $\beta$, and their growth can be inhibited only by antiestrogens [11].

Given the convolution of hormone receptor functions in prostate cancer cells [18], it could only be presented as a working hypothesis that, similar to MCF-7 breast cancer cells [6], the observed growth stimulation of PC3 and DU-145 cells by nanomolar concentrations of dihydro- $\mathbf{R}$ can be attributed to the hormone receptor modulation activity of this compound. A direct comparison between the three cell lines (MCF-7 [6], PC-3, and DU-145, Figure 4) reveals substantial similarities in dihydro- $\mathbf{R}$ biphasic proliferative action. As expected, the proliferative effects are more pronounced in the "classic" ER- $\alpha$-dependent MCF-7 cells compared to PC-3 cells (ER- $\alpha$ and ER- $\beta$ ) and then DU-145 cells (only ER- $\beta$ ).

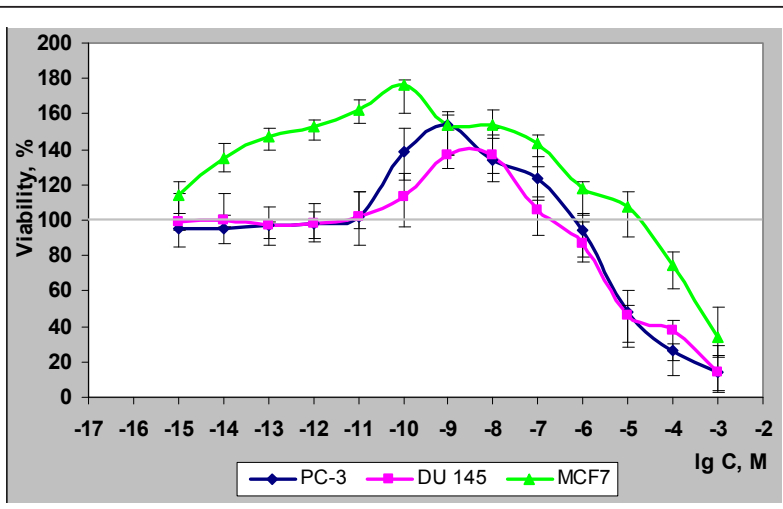

Figure 4 Biological activity of dihydro-R in PC-3, DU-145, and MCF-7 cell lines.

Additional credence is given to our assumption that dihydro- $\mathbf{R}$ is a hormone receptor modulator by the recent observation that another dietary polyphenol with a similar biological profile, genistein (Figure 5), also exhibits biphasic behavior in the regulation of prostate cancer cell growth [19]. It was reported that low $(5 \times$ $\left.10^{-7} \mathrm{M}\right)$ concentrations of genistein caused increased proliferation of PC-3 cells whereas a pharmacologic dose $\left(5 \times 10^{-5} \mathrm{M}\right)$ decreased proliferation. Estrogen signaling is mentioned as one of the possible mechanisms of this biphasic action [19] (genistein is a well-known phytoestrogen $[14,20,21])$.

To explore our working hypothesis further, we evaluated the cancer cell growth effects of dihydro- $\mathbf{R}$ in the presence of trans-R. Trans- $\mathbf{R}$ is capable of acting as both an estrogen and an antiestrogen [22-26], including non-genomic action [25], but this compound by itself does not significantly affect the growth of $\mathrm{PC}-3$ prostate cancer cells at concentrations below $1 \times 10^{-7} \mathrm{M}$. Our experiments clearly demonstrated the interference between dihydro- $\mathbf{R}$ and trans- $\mathbf{R}$ (Figure 6). In these experiments trans- $\mathbf{R}$ acted as a dihydro- $\mathbf{R}$ antagonist at low concentrations. The maximum antagonistic effect was observed at nanomolar concentrations $\left(1 \times 10^{-10}\right.$ to $\left.1 \times 10^{-8} \mathrm{M}\right)$. Similar biphasic agonistic/antagonistic properties of trans- $\mathbf{R}$ in MCF-7 cells in the presence of E2 were reported previously [24].

Somewhat stronger interference between dihydro- $\mathbf{R}$ and trans- $\mathbf{R}$ was observed in "classic" ER- $\alpha$-dependent MCF-7 cells (Figure 7). As we mentioned previously, dihydro- $\mathbf{R}$ proliferative action at very low concentrations was more pronounced in the MCF-7 cell line than the PC-3 cell line (Figure 4). As a result, cross-modulation effects of dihydro- $\mathbf{R}$ and trans- $\mathbf{R}$ in MCF-7 cells were notable even at sub-picomolar concentrations $\left(1 \times 10^{-16}\right.$ to $\left.1 \times 10^{-13} \mathrm{M}\right)$. This modulation appeared to be non-monotonic and showed a very complex concentration dependence pattern. For example, maximum proliferation effects of a $1 / 1$ 
<smiles>O=c1c(-c2ccc(O)cc2)coc2cc(O)cc(O)c12</smiles>

Genistein<smiles>CC12CCC3c4ccc(O)cc4CCC3[C@@H]1CCC2O</smiles>

$17 \beta-E s t r a d i o l(E 2)$

Figure 5 Structures of genistein and E2.

mixture of dihydro- $\mathbf{R}$ and trans- $\mathbf{R}$ were observed at $1 \times$ $10^{-14}$ and $1 \times 10^{-7} \mathrm{M}$ concentrations, whereas intermediate concentrations $\left(1 \times 10^{-11}\right.$ to $\left.1 \times 10^{-9} \mathrm{M}\right)$ showed little, if any, proliferative activity (Figure 7). Non-monotonic dose response is a well-documented feature of steroid hormone receptors $[27,28]$.

\section{Experimental Section}

Trans-R was obtained from Sigma (St. Louis, Missouri, USA). Cis-R was prepared from trans- $\mathbf{R}$ by photoisomerization [29]. Dihydro-R was synthesized from trans-R by catalytic hydrogenation according to $[7,29]$. The purity of the compounds was monitored by a combination of high performance liquid chromatograpy, ${ }^{1} \mathrm{H}$ nuclear magnetic resonance (NMR) and ${ }^{13} \mathrm{C}$ NMR. MCF-7, a human breast cancer cell line, and PC-3 and DU 145, human prostate cancer cell lines, were obtained from the American Type Culture Collection, Rockville, Maryland. Cell lines were cultured at $37^{\circ} \mathrm{C}$ in a $5 \% \mathrm{CO}_{2}$ humidified atmosphere and maintained in RPMI-1640 (Sigma, USA) supplemented with 10\% heat-inactivated $\left(56^{\circ} \mathrm{C}, 30 \mathrm{~min}\right)$ fetal calf serum (Hyclone Laboratories, Logan, UK), $2 \mathrm{mM}$ L-glutamine, and antibiotics (100 $\mu \mathrm{g} / \mathrm{ml}$ penicillin sodium salt and $100 \mu \mathrm{g} / \mathrm{ml}$ streptomycin sulfate [Sigma, USA], herein referred to as complete medium $[\mathrm{CM}])$. Resveratrol samples were dissolved in

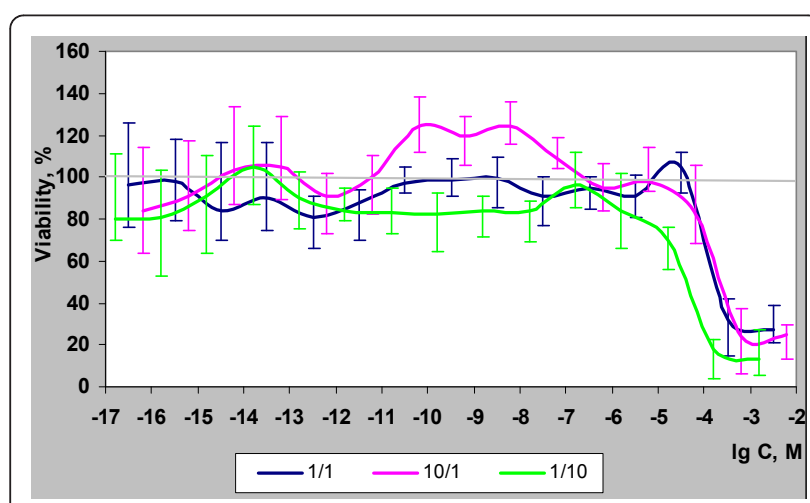

Figure 6 Biological activity of dihydro-R and trans-R mixtures $(1 / 1 ; 10 / 1 ; 1 / 10)$ in PC-3 cells. dimethyl sulfoxide (DMSO) (Sigma, USA) at a concentration of $200 \mathrm{mM}$, and diluted in culture medium just before use. Tumor cells were harvested, counted, suspended in CM, seeded into 96-well tissue culture plates (Costar, France) in $200 \mu \mathrm{l} /$ well at a concentration of $1 \times$ $10^{5} \mathrm{cell} / \mathrm{ml}$, and allowed to adhere overnight (required for particular cell lines to be in log phase). After that, $\mathrm{CM}$ was removed from sample wells. Compound sample solutions in CM were added to tumor cells. Final concentrations in sample wells amounted to $1 \times 10^{-15}-1 \times$ $10^{-3} \mathrm{M}$. The plates were incubated at $37^{\circ} \mathrm{C}$ in a $5 \% \mathrm{CO}_{2}$ humidified atmosphere for $48 \mathrm{~h}$. Three replica wells were used for controls and each compound concentration. The control samples contained DMSO concentrations corresponding to target compound dilutions. Every $24 \mathrm{~h}$ cells underwent microscopy and were photographed with the help of an AxioVision 4 system (Zeiss, Germany; see additional file 1 ). Cell viability assays were performed using 3-[4,5-dimethylthiazol-2-yl]-2,5-diphenyltetrazolium bromide (MTT) reduction. After a $48 \mathrm{~h}$ incubation of tumor cells (control or drug-treated), MTT solution $(5 \mathrm{mg} / \mathrm{ml})$ was added to each well. A $4 \mathrm{~h}$ incubation at $37^{\circ} \mathrm{C}$ was stopped by the addition of $100 \mu \mathrm{l}$ of DMSO. The absorbances of the samples were measured on a microplate reader Multiscan MS

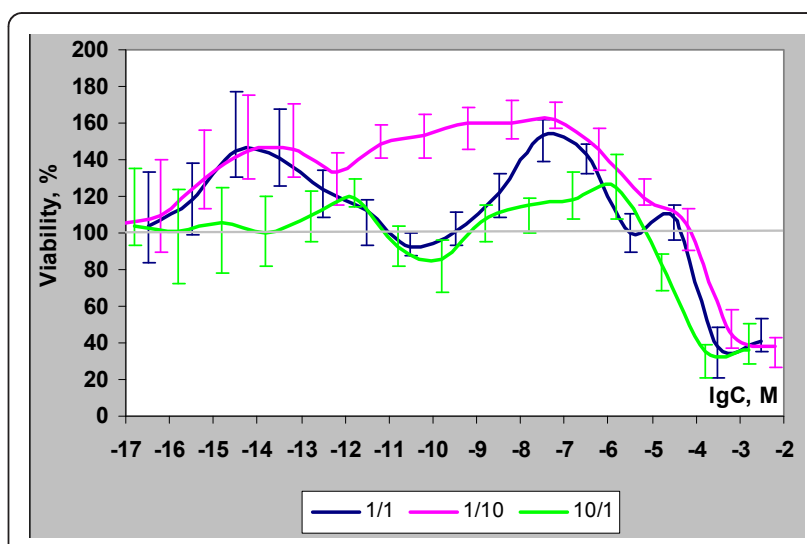

Figure 7 Biological activity of trans- $\mathrm{R}$ and dihydro- $\mathrm{R}$ mixtures $(1 / 1 ; 1 / 10 ; 10 / 1)$ in MCF-7 cells line. 
(Labsystem, Finland) at $540 \mathrm{~nm}$ after $30 \mathrm{~min}$ incubation at $37^{\circ} \mathrm{C}$. Cell viability was expressed as a relative viability of tumor cells (percent of control cultures incubated with medium only) and was calculated as follows: relative viability $=[(A e-A b) /(A c-A b)] \times 100$, where $A b$ is the background absorbance, $A e$ is the experimental absorbance, and $A c$ is the absorbance of untreated controls. The Statistica software package, version 6.0 (StatSoft) was used for statistical analysis.

\section{Conclusions}

We demonstrated that the biphasic proliferative effects of dihydro- $\mathbf{R}$ at picomolar and nanomolar concentrations are not limited to hormone-dependent breast cancer cells but also present, albeit in a reduced scale, in androgen-independent prostate cancer cells. While the exact mechanism of these effects requires further evaluation, our preliminary results point to hormone receptor modulation activity. A significant similarity exists between the phytoestrogens genistein and dihydro-R. We also observed strong cross modulation between trans- $\mathbf{R}$ and dihydro- $\mathbf{R}$, which is noticeable even at subpicomolar concentrations. The role of dihydro- $\mathbf{R}$ in breast cancer and prostate cancer proliferation related to moderate consumption of red wine remains an open question because dihydro-R exhibits proliferative activity in both prostate and breast cancer cells at low concentrations and has a very complex activity pattern in the presence of trans-R.

\section{Note Added in Proof}

The anti-cancer properties of trans- $\mathbf{R}$ go beyond direct growth inhibition of cancer cells. It is known that natural killer (NK) cells, such as mononuclear leukocytes (ML), are capable to kill tumor cells. We subsequently studied immunotropic activity of trans-R (Table 1, additional file 2). It was found that $10^{-6} \mathrm{M}$ of trans- $\mathbf{R}$ significantly activated lysis of K-562 cells by ML compared to intact ML: $61 \pm 6.8 \%$ vs. $46 \pm 5.8 \%$ for K-562/ML cell ratio $1: 10$; and $53 \pm 8.7 \%$ vs. $26 \pm 7.3 \%$ for $\mathrm{K}-562 / \mathrm{ML}$ cell ratio 1:5.

Our results are consistent with the general trends observed in the previous in vitro studies [30]. The

Table 1 NK-activity of ML after coincubation with trans-R.

\begin{tabular}{llll}
\hline $\begin{array}{l}\text { Concentration } \\
\text { trans-R in medium, } \mathbf{M}\end{array}$ & \multicolumn{3}{c}{ NK-activity } \\
& $\begin{array}{l}\text { K-562/ML } \\
\text { ratio 1:10 }\end{array}$ & $\begin{array}{l}\text { K-562/ML } \\
\text { ratio 1:5 }\end{array}$ & $\begin{array}{l}\text { K-562/ML } \\
\text { ratio 1:2 }\end{array}$ \\
\hline $10^{-5}$ & $52 \pm 7.9 \%$ & $48 \pm 10.8 \%$ & $7 \pm 2.2 \%$ \\
$10^{-6}$ & $61 \pm 6.8 \%$ & $53 \pm 8.7 \%$ & $5 \pm 3.4 \%$ \\
$10^{-7}$ & $45 \pm 5.7 \%$ & $28 \pm 3.8 \%$ & $4 \pm 1.9 \%$ \\
Control & $46 \pm 5.8 \%$ & $26 \pm 7.3 \%$ & $7 \pm 2.7 \%$ \\
\hline
\end{tabular}

authors [30] reported that in vitro exposure to trans- $\mathbf{R}$ produced a biphasic effect on the anti-CD3/anti-CD28induced development of both IFN-gamma-IL2 and -IL4producing $\mathrm{CD} 8+$ and $\mathrm{CD} 4+\mathrm{T}$-cells. Trans- $\mathbf{R}$ was found to induce a significant enhancement of NK cell cytotoxic activity at low concentrations and to induce suppression at high concentrations.

\section{Additional material}

Additional file 1: Cytotoxic activity of dihydro-R and trans-R

mixtures. Microscopic evaluation of the cytotoxic activity of dihydro- $\mathbf{R}$ and trans- $\mathbf{R}$ mixtures in MCF-7 and PC-3 cell lines.

Additional file 2: Immunotropic activity of trans-R. Microscopic evaluation of the immunotropic activity of trans-R in K-562 cell line.

\section{Acknowledgements}

The authors are grateful to Dr. M. Yu. Krasavin and M. V. Yudin for the preparation of trans-, cis-, and dihydro-resveratrol samples. This research was supported by the Global IPP program through the International Science and Technology Center. This paper is a contribution from the Discovery Chemistry Project. This effort was supported in part by NIDDK Intramural Research Program.

\section{Author details}

${ }^{1}$ N.N. Blokhin Russian Cancer Research Center of RAMS, Kashirskoe Shosse 24, Moscow, Russian Federation. ${ }^{2}$ Institute of General Patology and

Pathophysiology, 8 Baltiyskaya st., Moscow, 125315, Russian Federation. ${ }^{3}$ Chemical Diversity Research Institute, 2a Rabochaya St., Khimki, Moscow Reg., 141401, Russian Federation. ${ }^{4}$ National Institutes of Health, NIDDK, 8 Center Drive, Bethesda, MD 20892, USA.

\section{Authors' contributions}

NUA carried out biological experiments, participated in design of the study, and drafted the manuscript. MVK and AVS participated in coordination and design of the study. SVS carried out analysis of $\mathbf{R}$ samples, and participated in design of the study. INS carried out analysis of $\mathbf{R}$ samples. AAG participated in design and coordination of the study and edited the manuscript for publication. All authors have read and approved the final manuscript.

\section{Competing interests}

The authors declare that they have no competing interests.

Received: 21 July 2011 Accepted: 20 December 2011 Published: 20 December 2011

\section{References}

1. Renaud S, de Lorgeril M: Wine, alcohol, platelets, and the French paradox for coronary heart disease. Lancet 1992, 339:1523-1526.

2. Allen NE, Beral V, Casabonne D, Kan SW, Reeves GK, Brown A, Green J: Moderate Alcohol Intake and Cancer Incidence in Women. $J$ Natl Cancer Inst 2009, 101:296-305.

3. Li Y, Baer D, Friedman GD, Udaltsova N, Shim V, Klatsky AL: Wine, liquor, beer and risk of breast cancer in a large population. Eur J Cancer 2009, 45:843-850.

4. Newcomb PA, Nichols HB, Beasley JM, Egan K, Titus-Ernstoff L, Hampton JM Trentham-Dietz A: No Difference Between Red Wine or White Wine Consumption and Breast Cancer Risk. Cancer Epidem Biomar 2009, 18:1007-1010.

5. Schoonen WM, Salinas CA, Kiemeney LAL, Stanford JL: Alcohol consumption and risk of prostate cancer in middle-aged men. Int $J$ Cancer 2005, 113:133-140.

6. Gakh AA, Anisimova NY, Kiselevsky MV, Sadovnikov SV, Stankov IN, Yudin MV, Rufanov KA, Krasavin MY, Sosnov AV: Dihydro-resveratrol-A potent dietary polyphenol. Bioorg Med Chem Lett 2010, 20:6149-6151. 
7. Walle T, Hsieh F, DeLegge MH, Oatis JE, Walle UK: High Absorption but Very Low Bioavailability of Oral Resveratrol in Humans. Drug Metab Dispos 2004, 32:1377-1382.

8. Cardile V, Lombardo L, Spatafora C, Tringali C: Chemo-enzymatic synthesis and cell-growth inhibition activity of resveratrol analogues. Bioorg Chem 2005, 33:22-33.

9. Hsieh TC, Wu JM: Differential Effects on Growth, Cell Cycle Arrest, and Induction of Apoptosis by Resveratrol in Human Prostate Cancer Cell Lines. Exp Cell Res 1999, 249:109-115.

10. Carruba G, Pfeffer U, Fecarotta E, Coviello DA, D'Amato E, Casto ML, Vidali G, Castagnetta L: Estradiol Inhibits Growth of Hormonenonresponsive PC3 Human Prostate Cancer Cells. Cancer Res 1994, 54:1190-1193.

11. Lau KM, LaSpina M, Long J, Ho SM: Expression of Estrogen Receptor (ER)$\alpha$ and ER- $\beta$ in Normal and Malignant Prostatic Epithelial Cells: Regulation by Methylation and Involvement in Growth Regulation. Cancer Res 2000, 60:3175-3182.

12. Prins GS, Korach KS: The role of estrogens and estrogen receptors in normal prostate growth and disease. Steroids 2008, 73:233-244.

13. Mak P, Leung YK, Tang WY, Harwood C, Ho SM: Apigenin suppresses cancer cell growth through ERbeta. Neoplasia 2006, 8:896-904.

14. Shenouda NS, Zhou C, Browning JD, Ansell PJ, Sakla MS, Lubahn DB, Macdonald RS: Phytoestrogens in common herbs regulate prostate cancer cell growth in vitro. Nutr Cancer 2004, 49:200-208.

15. Benitez DA, Pozo-Guisado E, Alvarez-Barrientos A, Fernandez-Salguero PM, Castellon EA: Mechanisms Involved in Resveratrol-Induced Apoptosis and Cell Cycle Arrest in Prostate Cancer-Derived Cell Lines. J Androl 2007, 28:282-293.

16. Castagnetta LA, Miceli MD, Sorci CM, Pfeffer U, Farruggio $R$, Oliveri $G$, Calabrò M, Carruba G: Growth of LNCaP human prostate cancer cells is stimulated by estradiol via its own receptor. Endocrinology 1995, 136:2309-2319.

17. McPherson SJ, Hussain S, Balanathan P, Hedwards SL, Niranjan B, Grant M, Chandrasiri UP, Toivanen R, Wang Y, Taylor RA, Risbridger GP: Estrogen receptor- $\beta$ activated apoptosis in benign hyperplasia and cancer of the prostate is androgen independent and TNFa mediated. P Natl Acad SCi USA 2010, 107:3123-3128.

18. Zhu Y-S: Molecular Basis of Steroid Action in the Prostate. Cellscience 2005, 1:27-55.

19. El Touny LH, Banerjee PP: Identification of a Biphasic Role for Genistein in the Regulation of Prostate Cancer Growth and Metastasis. Cancer Res 2009, 69:3695-3703.

20. Adlercreutz H, Mazur W, Bartels P, Elomaa W, Watanabe S, Wähälä K, Landström M, Lundin E, Bergh A, Damber JE, Åman P, Widmark A, Johansson A, Zhang JX, Hallmans G: Phytoestrogens and Prostate Disease. I Nutr 2000, 130:658S-659S.

21. Adlercreutz H: Phytoestrogens: epidemiology and a possible role in cancer protection. Environ Health Perspect 1995, 103:103-112.

22. Gehm BD, MCAndrews JM, Chien PY, Jameson JL: Resveratrol, a polyphenolic compound found in grapes and wine, is an agonist for the estrogen receptor. P Natl Acad Sci USA 1997, 94:14138-14143.

23. Bowers $\mathrm{J}$, Tyulmenkov W, Jernigan $\mathrm{SC}$, Klinge CM: Resveratrol Acts as a Mixed Agonist/Antagonist for Estrogen Receptors a and $\beta$. Endocrinology 2000, 141:3657-3667.

24. Basly J-P, Marre-Fournier F, Le Bail J-C, Habrioux G, Chulia AJ: Estrogenic/ antiestrogenic and scavenging properties of (E)- and (Z)-resveratrol. Life Sci 2000, 66:769-777.

25. Benitez DA, Pozo-Guisado E, Clementi M, Castellon E, FernandezSalguero PM: Non-genomic action of resveratrol on androgen and oestrogen receptors in prostate cancer: modulation of the phosphoinositide 3-kinase pathway. Br J Cancer 2007, 96:1595-1604.

26. Levenson AS, Gehm BD, Pearce ST, Horiguchi J, Simons LA, Ward JE III, Jameson JL, Jordan VC: Resveratrol acts as an estrogen receptor (ER) agonist in breast cancer cells stably transfected with ER $\beta$. Int J Cancer 2003, 104:587-596.

27. vom Saal FS, Timms BG, Montano MM, Palanza P, Thayer KA, Nagel SC, Dhar MD, Ganjam VK, Parmigiani S, Welshons WV: Prostate enlargement in mice due to fetal exposure to low doses of estradiol or diethylstilbestrol and opposite effects at high doses. P Natl Acad Sci USA 1997, 94:2056-2061.
28. Li L, Andersen ME, Heber S, Zhang Q: Non-monotonic dose-response relationship in steroid hormone receptor-mediated gene expression. J Mol Endocrinol 2007, 38:569-585.

29. Stivala LA, Savio M, Carafoli F, Perucca P, Bianchi L, Maga G, Forti L, Pagnoni UM, Albini A, Prosperi E, Vannini V: Specific Structural Determinants Are Responsible for the Antioxidant Activity and the Cell Cycle Effects of Resveratrol. J Biol Chem 2001, 276:22586-22594.

30. Falchetti R, Fuggetta MP, Lanzilli G, Tricarico M, Ravagnan G: Effects of resveratrol on human immune cell function. Life Sci 2001, 70:81-96.

doi:10.1186/1752-153X-5-88

Cite this article as: Anisimova et al: Trans-, cis-, and dihydro-resveratrol: a comparative study. Chemistry Central Journal 2011 5:88.

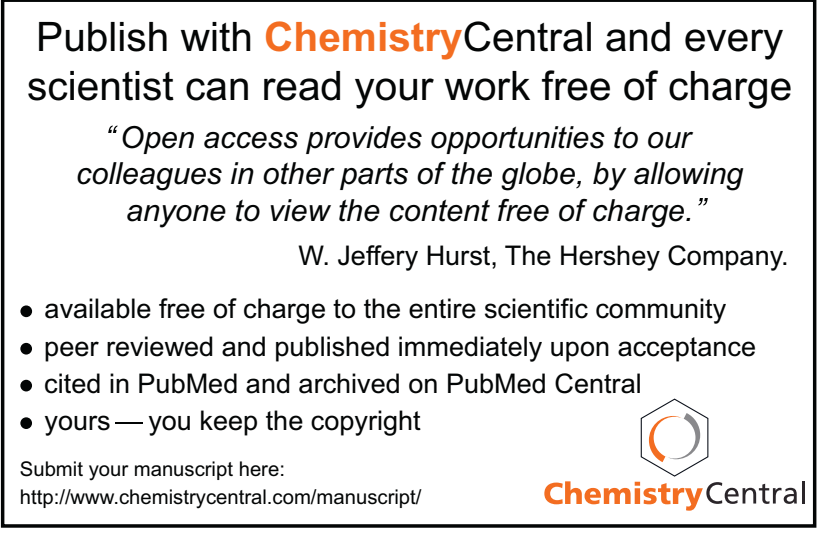

